\title{
Biofilm Bacteria and Cholesteatoma on Chronic Suppurative Otitis Media
}

\author{
Rosydiah Rahmawati', Nyilo Purnami ${ }^{2}$, Artono $^{2}$ \\ ${ }^{1}$ Researcher, ${ }^{2}$ Lecturer, Department of Otorhinolaryngology-Head and Neck Surgery, Faculty of Medicine, \\ Dr. Soetomo Teaching Hospital, Universitas Airlangga, Surabaya 60285, Indonesia
}

\begin{abstract}
Background: Chronic suppurative otitis media (CSOM) possibility to cause morbidity and mortality. Germ infections were a major factor in the long-standing inflammation of CSOM. Cholesteatoma is an epithelial cyst that containing keratin desquamation. The cholesteatoma present in CSOM patients is a kind of acquisita with several theories that have been believed to be the basis of its formation.
\end{abstract}

Objective: To explain the correlation between bacterial biofilms and cholesteatoma in CSOM.

Method: We performed the prospective collection of tissue during mastoidectomy surgery from CSOM patient. The tissue samples divided into two groups, cholesteatoma and non-cholesteatoma. All tissues group processed for scanning electron microscopy (SEM) analysis. The SEM results will be categorized into positive and negative bacterial biofilms.

Result: Statistical analysis using logistic regression test had $p=0.027$ and risk ratio $=5.55$. That means there was a significant correlation between bacterial biofilm and cholesteatoma in CSOM patients $(\mathrm{p}<0.05)$. CSOM with cholesteatoma has obtained the risk of bacterial biofilm by 5.55 times compared to CSOM without cholesteatoma.

Conclusion: There was a correlation between bacterial biofilms and cholesteatoma in CSOM patients. A quarter of cholesteatoma showed positive biofilms. CSOM with cholesteatoma has a risk of positive bacterial biofilm.

Keyword: Chronic Suppurative Otitis Media, Cholesteatoma, Bacterial Biofilm.

\section{Introduction}

Chronic suppurative otitis media (CSOM) possibility to cause morbidity and mortality that remains a major health problem in worldwide ${ }^{1}$. Morbidity and mortality are caused by cholesteatoma in patients with

\section{Corresponding Author:}

\section{Nyilo Purnami}

Lecturer Department of Otorhinolaryngology-Head and Neck Surgery, Faculty of Medicine, Dr. Soetomo Teaching Hospital, Universitas Airlangga, Surabaya 60285, Indonesia e-mail: nyilopurnamifkunair@yahoo.co
$\mathrm{CSOM}^{2}$. Cholesteatoma in CSOM is a decent media for biofilm bacteria $^{3-5}$. Biofilm bacteria in cholesteatoma are resistant to antibiotic administration resulting in persistent otorrhea that makes a wider damage and even more severe complications. This makes more complicates of the healing process CSOM patients with cholesteatoma $^{6,7}$.

The incidence of CSOM in Indonesia (1994-996) was to be about 8.36 million people and the prevalence of CSOM is generally about $3.8 \%$. Research at the Regional General Hospital of Dr. Soetomo in 0072008 got 61 cases of danger CSOM type that contains cholesteatoma and performed mastoidectomy surgery.

Cholesteatoma is an epithelial cyst that containing 
keratin desquamation. The cholesteatoma present in CSOM patients is a kind of acquisita with several theories that have been believed to be the basis of its formation. Cholesteatoma with infection is a synergy. Cholesteatoma, when formed are will continue to expand and absorb the water, therefore it is moist and invites infection. Debris cholesteatoma is a good culture medium for bacteria .

Germ infection is a major factor in the long-standing inflammation of CSOM. Some bacteria could be attached to the interface area, doing adhesions, aggregate and secrete the polysaccharide exopolymers that will form the glycocalyx matrix into biofilms ${ }^{6}$.

Biofilm bacteria get enough nutrition and have the ability to survive from unfavorable environments such as the body's natural response. Biofilm bacterial resistance to antibiotic administration is suspected through several mechanisms, ${ }^{8}$ namely: failure of penetration. decreased growth rate, metabolic activity and new phenotypic variations. The growth of biofilm bacteria will lead to chronic infection characterized by inflammation and persistent tissue damage. These chronic infections persist despite antibiotic therapy and inflammatory responses and immunity from patients ${ }^{9}$.

Research of biofilm bacteria on cholesteatoma of CSOM patients directly using electron scanning electron microscopy (SEM) that until now has not been done yet in Surabaya. From the above description researchers intend to conduct a study whether there was a correlation between bacterial biofilm and cholesteatoma in patients with CSOM who performed mastoidectomy surgery ${ }^{3,5}$.

\section{Method}

This research was an observational analytic research. This type of analytical research was used to observe the association between biofilm bacteria and cholesteatoma in CSOM. This study used a cross-sectional design that the data collection of biofilm bacteria and cholesteatoma in CSOM was performed simultaneously. The research was conducted in November 2013 to June 2014 at Lotus Room of Surgical Installation Center Dr. Soetomo Teaching Hospital, Surabaya and Technical Service Unit of Electron Microscopy Faculty of Medicine Universitas Airlangga.

The sample $(\mathrm{N}=33)$ of this research was CSOM patient which treated in Outpatient unit of otolaryngology Dr. Soetomo Teaching Hospital that planned a surgery mastoidectomy in invasive blood pressure (IBP) Dr. Soetomo Teaching Hospital. Tools for taking specimens (examination material) during mastoidectomy surgery was curettage \& forceps. Biofilm bacteria examination tool was SEM JEOL brand and JSM-T100 Scanning Microscope that made in Japan. The specimen drying apparatus was a Critical Point Drying (CPD) and coating device with Vacuum Evaporator. The required material was $2 \%$ Glutaraldehyde fixation solution, buffer phosphate, osmic acid and alcohol of various concentrations. Amyl acetate was a preservative and pure gold as a coating.

During mastoidectomy surgery at Dr. Soetomo Teaching Hospital, the operator takes a pathological tissue in the form of granulation tissue or cholesteatoma then inserted in $2 \%$ of glutaraldehyde fixation solution and stored in a cooler temperature of $4{ }^{\circ} \mathrm{C}$ for less than 2 hours. All the data collected were tabular and statistically, that processed using SPSS (SPSS. Inc. Chicago IL). It was conducted an inferential analysis to determine the correlation between bacterial biofilm and cholesteatoma in CSOM patients. The data obtained was nominal that will be analyzed statistically with logistic regression technique $(\alpha=0.05)$.

\section{Results}

Characteristics of Research Subject: In this study obtained the youngest age was 8 years and the oldest 61 years, while the mean age was 25.78 years $(\mathrm{SD}=13.90)$. The most age group was 11-20 years with 15 (45.45\%) patients (Table 1). The distribution based on sex was obtained by compared them, male: female $=1.1: 1$. Most of the age group was the male with $17(51.50 \%)$ patients (Table 1). Clinical characteristics of CSOM patients in this study was include type of perforation, audiometry results, mastoid photo and complications (Table 1). Clinical characteristics of patients with CSOM-save type has obtained the result that central perforation $(50 \%)$ as the most perforated type. Hearing loss conduction type (58.34\%) was the most number. Results of the most widely obtained mastoid image were the sclerotic type (75\%) (Table 1). Clinical characteristics of patients with CSOM danger-type the total perforation was obtained in $11(52.38 \%)$ patients. Results of mastoid images in the form of cavities were obtained $9(42.86 \%)$ patients and four patients not performed mastoid photos but computed tomograph (CT) scan. Fistel retro-auricular was the most common complication (Table 1). 
Table 1. Characteristics of Research Subject

\begin{tabular}{|c|c|c|}
\hline Characteristics of Reseacrh Subject & Amount & $\%$ \\
\hline $\begin{array}{l}\text { Age }(\mathbf{y} / \mathbf{0}) \\
<10 \\
11-20 \\
21-30 \\
31-40 \\
>40\end{array}$ & $\begin{array}{c}2 \\
15 \\
9 \\
2 \\
5\end{array}$ & $\begin{array}{c}6.06 \\
45.45 \\
27.27 \\
6.06 \\
15.16\end{array}$ \\
\hline $\begin{array}{l}\text { Sex } \\
\text { Male } \\
\text { Female }\end{array}$ & $\begin{array}{l}17 \\
16\end{array}$ & $\begin{array}{l}51.50 \\
48.50\end{array}$ \\
\hline $\begin{array}{l}\text { Type of perforation } \\
\text { Central } \\
\text { Total } \\
\text { Subtotal }\end{array}$ & $\begin{array}{l}6 \\
2 \\
4\end{array}$ & $\begin{array}{l}50.00 \\
16.67 \\
33.33\end{array}$ \\
\hline $\begin{array}{l}\text { Type of hearing loss } \\
\text { Conduction } \\
\text { Sensorineural } \\
\text { Mixed }\end{array}$ & $\begin{array}{l}7 \\
1 \\
4\end{array}$ & $\begin{array}{c}58.34 \\
8.33 \\
33.33\end{array}$ \\
\hline $\begin{array}{l}\text { Radiological results Mastoid Photo } \\
\text { Normal } \\
\text { Cataract } \\
\text { Sclerotic } \\
\text { Computed tomograph Scan } \\
\text { Complication }\end{array}$ & $\begin{array}{l}2 \\
1 \\
9 \\
0 \\
0\end{array}$ & $\begin{array}{c}16.67 \\
8.33 \\
75.00 \\
0 \\
0\end{array}$ \\
\hline $\begin{array}{l}\text { Tympanic membrane conditions } \\
\text { Perforation Atik } \\
\text { Perforation Total } \\
\text { Perforation Marginal } \\
\text { Adesive }\end{array}$ & $\begin{array}{c}5 \\
11 \\
3 \\
2\end{array}$ & $\begin{array}{c}23.81 \\
52.38 \\
14.29 \\
9.52\end{array}$ \\
\hline $\begin{array}{l}\text { Type of hearing loss } \\
\text { Conduction } \\
\text { Sensorineural } \\
\text { Mixed } \\
\text { Un-treated }\end{array}$ & $\begin{array}{c}10 \\
1 \\
7 \\
3\end{array}$ & $\begin{array}{c}47.62 \\
4.76 \\
33.33 \\
14.29\end{array}$ \\
\hline $\begin{array}{l}\text { Radiological Results Mastoid photo } \\
\text { Cavity } \\
\text { Sclerotic } \\
\text { CT-Scan } \\
\text { Destruction of the mastoid cavity } \\
\text { Abses Bezold. fistula kavum mastoid } \\
\text { Cerebral abscess without mastoid destruction } \\
\text { Mastoiditis. fistula cavum mastoid }\end{array}$ & $\begin{array}{l}9 \\
8 \\
1 \\
1 \\
1 \\
1\end{array}$ & $\begin{array}{r}42.86 \\
38.09 \\
4.76 \\
4.76 \\
4.76 \\
4.76\end{array}$ \\
\hline $\begin{array}{l}\text { Complication } \\
\text { Abses retroaurikula } \\
\text { Fistel retroaurikula } \\
\text { Abses serebri } \\
\text { Abses zygoma } \\
\text { Abses Bezold } \\
\text { Parese N.VII }\end{array}$ & $\begin{array}{l}2 \\
4 \\
1 \\
2 \\
1 \\
1\end{array}$ & $\begin{array}{c}9.52 \\
19.05 \\
4.76 \\
9.52 \\
4.76 \\
4.76\end{array}$ \\
\hline
\end{tabular}


Table 2. Types of mastoidectomy surgery $\&$ pathological tissue

\begin{tabular}{|l|c|c|c|}
\hline \multirow{2}{*}{$\begin{array}{l}\text { Type of mastoidectomy } \\
\text { surgery }\end{array}$} & Cholesteatoma & Non-cholesteatoma & \multirow{2}{*}{ Total } \\
\cline { 2 - 4 } & $16(48.48 \%)$ & $5(15.16 \%)$ & $21(63.64 \%)$ \\
Canal wall down & 0 & $12(36.36 \%)$ & $12(36.36 \%)$ \\
Canal wall up & 16 & 17 & $33(100 \%)$ \\
\hline Total & & & \\
\hline
\end{tabular}

Table 3. Biofilm bacteria examination results from cholesteatoma and non-cholesteatoma tissue in patients with CSOM

\begin{tabular}{|l|c|c|c|c|}
\hline \multirow{2}{*}{ Tissue types } & \multicolumn{2}{|c|}{ Bacterial Biofilm } & \multirow{2}{*}{ Total } & Regression \\
\cline { 2 - 3 } & $\mathbf{( + )}$ & $\mathbf{( - )}$ & & Logistic \\
\hline Cholesteatoma & $12(75.0 \%)$ & $4(25.0 \%)$ & $16(100 \%)$ & $\mathrm{p}=0.027$ \\
\hline Non-cholesteatoma & $6(35.3 \%)$ & $11(64.7 \%)$ & $17(100 \%)$ & $\mathrm{rr}=5.55$ \\
\hline Total & $\mathbf{1 8 ( 5 4 . 5 \% )}$ & $\mathbf{1 5}(\mathbf{4 5 . 5 \% )}$ & $\mathbf{3 3 ( 1 0 0 \% )}$ & \\
\hline
\end{tabular}

The types of canal wall down mastoidectomy surgery was performed on $21(63.64 \%)$ patients and mastoidectomy surgery canal wall up performed on $12(36.36 \%)$ patients. Non-cholesteatoma tissue (granulation) was obtained in 17 (51.52\%) patients and total cholesteatoma tissue was obtained in 16 (48.48\%) patients (Table 2). The result of examination of 33 operational tissues was obtained biofilm (+) on 18 (54.54\%) tissue and biofilm (-) at15 (45.46\%) network (Table 3).

\section{Correlation Results of Bacterial Biofilm} Analysis and Cholesteatoma in CSOM: The results of bacterial biofilm examination on cholesteatoma and non-cholesteatoma tissue. The examination was performed on 33 tissue mastoidectomy that resulting 16 cholesteatoma tissue and 17 non-cholesteatoma tissues. The results of the cholesteatoma tissue examination were obtained by biofilm bacteria $(+)$ by $12(75 \%)$ tissues and bacteria biofilm (-) by $4(25 \%)$ tissue. The results of non-cholesteatoma tissue examination were obtained 6 (35.35\%) biofilm bacteria (tissue) and biofilm bacteria (-) of $11(67.9 \%)$ tissues. The statistical test with logistic regression was obtained $\mathrm{p}=0.027$ and risk ratio $=5.55$. It means that there was a correlation between bacterial biofilm and cholesteatoma in patients with CSOM (p $<0.05$ ) and cholesteatoma in CSOM as a risk factor for biofilm bacteria (Table 3 ).

\section{Discussion}

Basic Data: The results of this study indicate that there was a correlation between CSOM and cholesteatoma and without cholesteatoma with bacteria biofilm on the mastoid mucosa. The study also showed higher biofilm bacteria incidence in CSOM with cholesteatoma than CSOM without cholesteatoma. The difference between the two groups of CSOM on the presence of biofilm bacteria was statistically significant ${ }^{3}$.

The results of this study support the theory that biofilm bacteria that have an important role in the aggressiveness of cholesteatoma in CSOM. Biofilm bacteria were obtained more in the cholesteatoma group than in the group without cholesteatoma with a risk ratio value of 5.55. This suggests that cholesteatoma in CSOM was a risk factor for the formation of biofilm bacteria ${ }^{3}$.

The results of this study obtained bacteria biofilm (-) on $4(25 \%)$ tissue cholesteatoma. Based on previous research bacteria biofilm is often found in cholesteatoma and there was a statistically significant relationship, however, biofilm bacteria was not a typical structure in cholesteatoma. Other causes of bacteria were not obtained in the form of biofilm because bacteria separate themselves from colonies into planktonic forms. This possibility occurs in mature biofilms and favorable environmental conditions $3,4,10,11$.

This research has obtained a bacteria biofilm $(+)$ on $6(35.3 \%)$ of non-cholesteatoma tissue. This result was not a new discovery because it was also found in previous studies with a percentage of $14 \%-54.5 \%$. This due to the humid and warm conditions in the middle 
ear, ear canal and mastoid cavity in CSOM. CSOM without active-phase cholesteatoma was a good medium for bacteria to attach to the interface area. The type of bacteria that infects could also affect the formation of biofilms. Although the number was small its needed to be watched by otolaryngology specialists.

The characteristics of age were in accordance with WHO (2004) data which states that the prevalence of CSOM based on surveys in some countries that obtained in many school-age children. The incidence of CSOM with cholesteatoma in the United States of children aged 10-19 was found in 9.2 cases in 100.000 population. Similarly, in Israel, there was the incidence of CSOM with cholesteatoma in children aged $1-15$ years by 39 cases in every 100.000 population ${ }^{2}$.

Central perforation was including the safe type of CSOM because it is present a pars tensa and all edges of the perforation still have the rest of the tympanic membrane. Group of dangerous CSOM types are 3 patients who do not do audiometric examination because of patients with intracranial complications that do not meet the requirements of audiometric examination. Hearing loss in this study was similar to some previous studies. Rambe (2002) reported a type of hearing loss from 94 ears of CSOM patients who were conductive deafness was $75(79.8 \%)$ of the ear, deafness was 16 (17\%) ear and nerve deaf was $3(3.2 \%)$ ear.

Results of the mastoid photo on most dangeroustype of CSOM was the form of a cavity. The shape of the cavity in the mastoid photo was due to the process of bone destruction as a result of the interaction between cholesteatoma and various inflammatory mediators. The results of radiological evaluation of this study were in accordance with previous research in patients with dangerous-type of CSOM that has obtained the description of destruction by 51 patients, sclerotic in 8 patients, while 9 patients performed CT scan. Fistel retroauricular were almost always due to cholesteatomas that not adequately treated. ${ }^{2}$.

The number of complications in this study was more than the research in the same place that shows patients of dangerous-type of CSOM by 39\% that experienced complications. The study reported a cerebral abscess as the highest number of $28 \%$ followed by fistel retroauricular and subperiosteal abscess respectively $24 \%$. There was no definite factor to explain the occurrence of the different complications experienced by each patient. However, this possibility due to the immune system between different individuals, the delay that came to the doctor, inadequate therapy and the possibility of genetic involvement.

Operation mastoidectomy canal wall down was breaking down meatus acusticus externus (MAE) posterior wall that separates the tympanic cavity with the mastoid cavity. Mastoidectomy operation of canal wall up trying to maintain MAE posterior wall ${ }^{2}$. This complication might be due to the role of inflammatory mediators that could stimulate proteolytic enzymes resulting in bone destruction around granulation. In addition, complications could occur hematogen ${ }^{12}$.

Cholesteatoma that associated with CSOM was a type of acquisition. Cholesteatoma causes erosion of the affected bone through the effects of suppression by keratin debris accumulation as well as the mediation of osteoclast-mediated enzyme-mediated by inflammatory mediators. Bone resorption possibility causes the destruction of the mastoid trabeculae, oleic erosion, labyrinth fistula, Nervus VII (N VII) exposure, duramater and lateral sinuses.

In this study, the tissue with a positive biofilm found the form of coccus bacteria clustered and surrounded by the formation of amorphous materials in the form of glycocalyx. While on the network with negative biofilm found the formation of bacteria coccus but not clustered or shaped sesil and not glycocalyx formation. This study was in accordance with previous studies conducted on the middle ear tissue of CSOM patients performed tympanomastoid surgery ${ }^{13,14}$.

\section{Conclusion}

There was a correlation between bacteria biofilm and cholesteatoma in patients with CSOM. A quarter of cholesteatoma showed positive biofilms. Also, cholesteatoma was a risk factor for the formation of biofilm bacteria.

Ethical Clearance: This research involves participants in the process using a questionnaire that was accordant with the ethical research principle based on the regulation of research ethic regulation. The present study was carried out in accordance with the research principles. This study implemented the basic principle ethics of respect, beneficence, non-maleficence and justice. 
Conflict of Interest: The authors have not found any conflict of interest related to this research so far.

Source of Funding: All of the cost and fees related with this research are paid by the authors only with no sponsorship nor external funds.

\section{References}

1. Widodo A, Soepriyadi. Diagnosis Otitis Media. J THT-KL. 2008;1:41-8.

2. WHO. Chronic suppurative otitis media: burden of illness and management options. Switzerland: Geneve: World Health Organization; 2004.

3. Lampikoski H, Aarnisalo AA, Jero J, Kinnari TJ. Mastoid Biofilm in Chronic Otitis Media. Otol Neurotol. 2012;33:785-8.

4. Kaya E, Dag I, Incesulu A, Gurbuz MK, Acar M, Birdane L. Investigation of the Presence of Biofilms in Chronic Suppurative Otitis Media, Nonsuppurative Otitis Media and Chronic Otitis Media with Cholesteatoma by Scanning Electron Microscopy. Sci World J. 2013;2013:1-6.

5. Mason RJ, Broaddus VC, Martin TR, King TE, Schraufnagel D, Murray JF, et al. Murray and Nadel's Textbook of Respiratory Medicine E-Book: 2-Volume Set. Elsevier Health Sciences; 2010.

6. Vlastarakos P V., Nikolopoulos TP, Maragoudakis P, Tzagaroulakis A, Ferekidis E. Biofilms in Ear, Nose and Throat Infections: How Important are They? Laryngoscope. 2007;117:668-73.

7. Artono, Surarto B, Purnami N, Hutahaen F, Mahardhika MR. The Association of IL-1 Alpha Level and TNF Alpha Expressions on Bone Destruction in Chronic Suppurative Otitis Media and Cholesteatoma. Indian J Otolaryngol Head Neck Surg. 2019.
8. Zhao L, Sun T, Wang L. Chitosan oligosaccharide improves the therapeutic efficacy of sitagliptin for the therapy of Chinese elderly patients with type 2 diabetes mellitus. Ther Clin Risk Manag [Internet]. 2017;13:739-50. Available from: https://www.scopus.com/ inward/record.uri?eid=2-s2.0-85021637024 \& doi $=10.2147 \% 2$ FTCRM.S134039 \& partnerID $=40$ $\& \mathrm{md} 5=3 \mathrm{c} 3 \mathrm{f} 8 \mathrm{f} 15 \mathrm{ad} 71 \mathrm{ecd} 8 \mathrm{c} 6 \mathrm{~d} 7 \mathrm{ec} 3208556 \mathrm{e} 3 \mathrm{c}$

9. Kriswandini I, Rahardjo M, Budi H, Amalia $\mathrm{R}$. The difference in biofilm molecular weight in Streptococcus mutans and Aggregatibacter actinomycetemcomitans induced by sucrose and soy protein (Glycine Soja). Indian J Dent Res. 2019;30:273.

10. Hall-Stoodley L, Costerton JW, Stoodley P. Bacterial biofilms: from the Natural environment to infectious diseases. Nat Rev Microbiol. 2004;2:95108.

11. Chole RA, Faddis BT. Evidence for Microbial Biofilms in Cholesteatomas. Arch Otolaryngol Neck Surg. 2002;128:1129.

12. Juhn SK, Jung M-K, Hoffman MD, Drew BR, Preciado DA, Sausen NJ, et al. The Role of Inflammatory Mediators in the Pathogenesis ofOtitis Media and Sequelae. Clin Exp Otorhinolaryngol. 2008;1:117.

13. Astuti S, Mukhammad Y, Duli SJ, Putra A, Setiawatie E, Triyana K. Gas sensor array system properties for detecting bacterial biofilms. J Med Signals Sensors. 2019;9:158.

14. Pinar E, Öncel S, Karagöz Ü, Şener G, Çalli Ç, Tatar B. Demonstration of bacterial biofilms in chronic otitis media. Mediterr J Otol. 2008;4:64-8. 